\title{
Hair Trace Elements in Children With Autism Spectrum Disorders: Systematic Literature Review
}

Marcin Mikulewicz ( $\nabla$ marcin.mikulewicz@umed.wroc.pl )

Uniwersytet Medyczny im Piastow Slaskich we Wroclawiu https://orcid.org/0000-0001-5754-0284

Katarzyna Chojnacka

Wroclaw University of Technology: Politechnika Wroclawska

\section{Research}

Keywords: hair mineral analysis, trace elements, environmental exposure, pathogenesis, neurotoxicity

Posted Date: February 8th, 2021

DOI: https://doi.org/10.21203/rs.3.rs-163074/v1

License: () (7) This work is licensed under a Creative Commons Attribution 4.0 International License. Read Full License 


\section{Abstract}

(1) Background: The aim of this work was to systematically review the literature on the relation between the levels of elements in hair (toxic elements and trace elements) on the occurrence of autism spectrum disorder.

(2) Methods: Search strategy and study selection: Original articles were included if they met the including criteria that report the trace element levels in hair. The following databases were screened: Medline (via PubMed), Scopus, Web of Science, Google Scholar (from 2000.01.01 to 2020.11.11). The main search terms used were "hair element analysis and trace elements and autism".

(3) Results: The papers available describe results of studies undertaken with the use of different methodology: diversified size of experimental groups, different sampling and analytical techniques. Therefore direct comparison of the results is not informative.

(4) Conclusions: It was found that pathogenesis of autism spectrum disorder was associated with the exposure to toxic elements (e.g. $\mathrm{Hg}$ and Pb) which act as neurotoxicants. Also, the relation between some microelements seem to be significant, in particular the ratio $\mathrm{Zn} / \mathrm{Cu}$. Higher level of zinc and level levels of copper play the protectory role.

\section{Introduction}

\section{Autism spectrum disorder (ASD)}

The scientific literature shows that environmental exposure to toxic elements may have an impact on the occurrence of neurodevelopmental diseases, including autism spectrum disorder (ASD) - the symptoms of which include intellectual disabilities, social interaction deficit, repetitive behavioral patterns and cognitive impairment [1]. The pathogenesis of ASD are both environmental and genetic factors that alter physiological processes during development. Environmental toxins undoubtedly influence neurological development. Among the neurotoxic metals that could contribute to ASD: $\mathrm{Cd}, \mathrm{Pb}$, $\mathrm{Hg}$, $\mathrm{Ni}$ and $\mathrm{Mn}$ are mentioned [2].

The global number of autism cases still increases. Therefore, intensive research is ongoing to identify the factors contributing to the occurrence of ASD. Factors related to environmental pollution and genetics are mentioned [3]. ASD is associated with inflammatory neuronal damage. The causes of neuronal injury include various external conditions that lead to developmental disorders. The most common environmental factors are listed: lead, methyl-mercury, polychlorinated biphenyls, polybrominated diphenyl ethers, organophosphate pesticides, organochlorine pesticides, endocrine disruptors, polycyclic aromatic hydrocarbons, automotive fumes and perfluorinated compounds. However, the greatest role is assigned to mercury and its compounds. Kern et al., 2016 [4] reviewed 91 studies that were published between 1999 and 2016. As many as 74\% of these studies proved a close relationship between exposure to mercury and the occurrence of ASD [4].

On the basis of epidemiological studies, the following developmental neurotoxicants are identified that contribute to the occurrence of ASD pathology: lead, methylmercury, polychlorinated biphenyls, arsenic and toluene. The greatest role is assigned to mercury compounds, especially methylmercury. However, the indicated sources of exposure to mercury raise discussion: methylmercury (found in fish), ethylmercury (thiomersal in vaccines), mercury vapors (dental amalgams) [4]. Research has shown that areas with high levels of lead and mercury emissions to the air are related with more cases of autism. There is a correlation between the incidence of autism and the children exposure to mercury from the mother's fillings, from the environment, or from seafood [5]. Since literature proves that autism is related with exposure to toxic elements, the use of hair mineral analysis to identify the link between ASD and status of chemical elements in the organism of autistic children can be useful to investigate the mechanism of ASD, possible mitigation measures, as elaboration of detoxification protocols.

In assessing the elemental status of a human, various biological matrices can be used: blood, urine, serum and blood plasma, saliva, nails or hair [7] [8].

\section{Biomarkers of exposure in research and ASD}

\section{Blood}

Blood is not a recommended biomarker as the blood half-life of mercury is several weeks. Therefore, chronic exposure biomarkers are used [5].

Teeth

The content of $\mathrm{Hg}, \mathrm{Pb}$ and $\mathrm{Zn}$ in teeth was assessed. It was shown that the level of $\mathrm{Hg}$ was 2 times higher in the teeth of autistic children (a statistically significant difference). The $\mathrm{Pb}$ content was $30 \%$ higher, but it was not a statistically significant difference. The content of $\mathrm{Zn}$ was similar. This suggests that prenatal exposure to mercury is the confirmation that mercury is a neurodevelopmental toxin responsible for the development of autism [6].

Hair Mineral Analysis as a useful tool in the assessment of the effect of chemical elements status in disorders

Human hair contains about 10 times higher level of trace elements. Therefore, their detectability in biological material is higher. The content of elements in human hair is determined by various factors: both exogenous (air and water pollution) and endogenous (metabolic pathways) [9]. The usefulness of hair mineral analysis is related with its non-invasiveness and ease of sampling [10]. However, there are interpretation problems related to the influence of individual factors on the content of elements in hair. 
In the case of elemental analysis of children's hair, the problem is even more complex as this group is more susceptible to contact with trace elements [11], have low detoxification and excretion capacity and high absorption rate [9]. Compared to other matrices, hair grows slowly and the accumulation window is wide [7]. The methodology of research on human hair is to determine the standardized baseline of the content of elements in hair, taking into account the population of healthy and non-exposed people [12]. In this way, reference ranges are established. As a rule, gender is the criterion for dividing into groups. Additional criteria are lifestyle, diet, hair thickness and determination, how fast it grows [13].

Studies using hair as an exposure marker rely on the assessment of exposure to specific chemicals with a known dose-effect relationship. Baseline values are set for specific population groups and the populations at risk are identified, taking into account the influence of specific factors: toxicological or nutritional risk. This also has an impact on legislative action. Hair is a non-invasive matrix, easy to store and transport, and its main advantage is a wide time window for exposure assessment [14] [15]. While hair mineral analysis is an attractive biomarker of exposure to toxic elements, there are more questions than answers regarding the validity of this method in diagnostics of elemental status [16]. There are still controversies regarding the use of hair mineral analysis as a diagnostic method. It is related to the multitude of factors that affect reference values. It is imperative to follow an appropriate hair washing procedure before the analysis in order to remove elements related to the outer surface of the hair [17].

HMA should reflect internal exposure. Integrates all exposure sources and absorption routes. Obviously, testing the exposure to elements should take into account the individual variability and its kinetics, in particular absorption, distribution, metabolism and excretion [18] [19]. The level of trace elements in hair reflects the average status of the body, assuming that hair grows at a rate $1 \mathrm{~cm}$ per month. The analyte content in this matrix reflects the condition of the body and provides information on historical exposure from water, food by dermal exposure. HMA is considered to be a good screening tool in assessing the status of the human body with regard to essential and toxic elements, because the hair incorporates elements into its structure during growth [20]. Unlike other tissues, hair grows outside the skin and eliminates toxic elements from metabolic processes [21].

\section{Examples of using HMA}

Many studies confirm that HMA is useful in assessing human exposure to toxic elements. There are many examples confirming the relation between the exposure and the content of elements in hair. For instance, mineral hair analysis was used to assess the exposure of the population to arsenic from groundwater contaminated with arsenic and other toxic elements [22]. Such monitoring studies are combined with population surveys to identify additional factors that influence the mineral composition of the hair, such as gender, dietary and environmental exposure, diseases or medications [23].

Hair mineral analysis is used for workplace exposure assessment. For example, the usefulness of HMA has been proven to be useful in evaluation of the exposure to $\mathrm{Fe}, \mathrm{Zn}, \mathrm{Mn}$ and $\mathrm{P}$ in welder and steelworkers for assembly personnel [24] [25].

Since elements were found to contribute significantly to the pathogenesis of ASD and HMA was found to be useful in determination of elements status of human organism, the aim of this work was to systematically review the literature on the relation between the levels of elements in hair (toxic elements and trace elements) on the occurrence of autism spectrum disorder.

\section{Materials And Methods}

Search strategy and study selection: original articles were included if they met the including criteria: studies that measured levels of trace elements in hair; articles that provided sufficient data, including the total number of subjects in both investigated and control groups that report mean or median and standard deviation (SD) of the trace element levels in hair; English language. The titles and abstracts were read to find eligible studies and thus their full texts were obtained. The references in retrieved studies were checked. The following databases were screened: Medline (via PubMed), Scopus, Web of Science, Google Scholar (from 2000.01.01 to 2020.11.11) The search strategy combined MeSH heading words with free-text words. The main search terms used were "hair element analysis and trace elements and autism". Prisma diagram is presented in Fig. 1. Key words used in electronic search in databases: PubMed ((hair element analysis) AND (trace elements) AND (autism)), Web of Science ((hair element analysis) AND (trace elements) AND (autism)), Google Scholar ((hair element analysis) AND (trace elements) AND (autism)). Exclusion criteria: systematic reviews, case reports, reviews.

\section{Results}

The search retrieved eventually 12 original papers that met the inclusion criteria that reported the relation between the level of elements in hair in ASD children. Table 1 reports the main objectives, materials, methodology and conclusions. Tables 2 and 3 present results (essential trace and toxic elements). The majority of studies show different approach to methodology: different methods of sampling, diversified analytical methods, different sizes of experimental groups. Also the results are reported in different manner: as mean, median or percentile range. Therefore it is difficult to compare the absolute values. 
Table 1

Studies included in the systematic review

Ref. Main objective

[26] Assessment of hair trace element and mineral levels in boys with ADHD, ASD, as well as ADHD with ASD.

[27] Associations between the hair levels of metals and essential elements and some specific features of ASD.

No of patients/sex/age

Analytical technique/unit

M 52 (ASD) ICP-MS

CTR 52

Age $^{\star} 5.18 \pm 1.00$

ASD 48

M 34

F 14

Age: $6.5 \pm 3.8$

[28] Investigation the trace element and gut microbiota

ASD $78 \quad$ ICP-MS
profiles of Chinese autistic children.

M 56

F 22

58 CTR

Age: $4.96 \pm 1.01$

[29] Investigation of the association between catatonia in autism spectrum disorder (ASD) and the levels of trace elements in hair and serum.

30

ICP-MS

ASD + CAT 30

M 30

CTR 30

[30] Evaluation the levels of essential trace elements in hair and serum in children with autism spectrum disorder.

ASD 70

M40

F30

CTR 70

Age $6.4 \pm 2.9$

Two groups:

$(2-5)$

$(6-10)$

[31] Analysis of hair trace elements content in children with communication disorder and autism spectrum disorder.

ASD 33**

ICP-MS

M 33

CTR 33

Age: $5.0 \pm 1.8$

Two groups:

[32] Investigation of hair trace elements content in children suffering from autism spectrum disorder (ASD).
ASD $74 \quad$ ICP-MS

CTR 74

AGE: two groups:

$(5-9)$

\section{Main conclusions}

The obtained results suggest that elements, such as $\mathrm{Mg}, \mathrm{Mn}$ and $\mathrm{Zn}$ may have an impact on the development of ADHD and ASD.

\section{ICP-MS}

The obtained results show the relationship of metallomic analysis with the essential features of ASD in order to identify potential environmental risk factors at the individual level.

The results obtained in Chinese children with ASD indicate significant changes in the profile of micronutrients and intestinal microbiota.

\section{ICP-DRC-MS}

(CP.DRCMS

To develop a personal diet for patients with ASD, it is recommended to evaluate several bioindication matrices to critically assess the status of trace elements in patients.
The results showed (regression) that $\mathrm{Hg}$ levels in hair were negatively associated with catatonia in ASD in raw and corrected models. 


\begin{tabular}{|c|c|c|c|c|}
\hline Ref. & Main objective & $\begin{array}{l}\text { No of } \\
\text { patients/sex/age }\end{array}$ & $\begin{array}{l}\text { Analytical } \\
\text { technique/unit }\end{array}$ & Main conclusions \\
\hline \multirow[t]{4}{*}{ [33] } & \multirow{4}{*}{$\begin{array}{l}\text { Determination of human scalp hair concentrations } \\
\text { of trace elements. }\end{array}$} & ASD 1,967 & \multirow[t]{4}{*}{ ICP-MS } & \multirow{4}{*}{$\begin{array}{l}\text { Zinc and magnesium deficiency may play an } \\
\text { important role in the pathogenesis of autism. }\end{array}$} \\
\hline & & M 1,553 & & \\
\hline & & F 414 & & \\
\hline & & Age: $0-15$ & & \\
\hline \multirow[t]{5}{*}{ [34] } & \multirow{5}{*}{$\begin{array}{l}\text { Examination of possible environmental risk factors } \\
\text { and sources of exposure to mercury in children with } \\
\text { autism. }\end{array}$} & ASD 25 & \multirow[t]{5}{*}{ ICP-MS } & \multirow{5}{*}{$\begin{array}{l}\text { The baseline levels of arsenic, cadmium and cerium } \\
\text { in urine did not reflect statistically significant } \\
\text { differences of these elements in mean levels in hair. }\end{array}$} \\
\hline & & M 22 & & \\
\hline & & F 3 & & \\
\hline & & CTR 25 & & \\
\hline & & Age: 3-9 & & \\
\hline \multirow[t]{5}{*}{ [35] } & \multirow{5}{*}{$\begin{array}{l}\text { Investigation of the levels of both toxic and } \\
\text { essential metals in the hair of autistic children. }\end{array}$} & ASD 44 & \multirow[t]{5}{*}{ ICP-MS } & \multirow{5}{*}{$\begin{array}{l}\text { The results of the current study (as well as the } \\
\text { previous one) assessing the concentration of } \\
\text { elements in the hair - when it comes to } \mathrm{Hg} \text { - are not } \\
\text { meaningful. }\end{array}$} \\
\hline & & M 37 & & \\
\hline & & F 7 & & \\
\hline & & CTR 61 & & \\
\hline & & Age: $9.00 \pm 4.05$ & & \\
\hline \multirow[t]{6}{*}{ [36] } & \multirow{6}{*}{$\begin{array}{l}\text { Assessment of the levels of trace elements in the } \\
\text { hair and nail samples of autistic children. }\end{array}$} & ASD 45 & \multirow[t]{6}{*}{ AAS } & \multirow{6}{*}{$\begin{array}{l}\text { Zn showed significantly different level in hair and } \\
\text { nails, } \mathrm{Cu}, \mathrm{Pb} \text { and } \mathrm{Hg} \text { - increased concentration, and } \\
\mathrm{Mg} \text { and } \mathrm{Se} \text { decreased concentration (hair, nails) in } \\
\text { people with autism vs. control. }\end{array}$} \\
\hline & & LFA/MFA/HFA*** & & \\
\hline & & 15 each & & \\
\hline & & CTR 50 & & \\
\hline & & $M: F=4: 1$ & & \\
\hline & & Age: $4-12$ & & \\
\hline \multirow[t]{4}{*}{ [37] } & \multirow{4}{*}{$\begin{array}{l}\text { Concentration of toxic metals in the hair of children } \\
\text { with autism. }\end{array}$} & ASD 40 & \multirow[t]{4}{*}{ ICP-MS } & \multirow{4}{*}{$\begin{array}{l}\text { Lead, mercury and uranium - higher content in the } \\
\text { hair of children with autism. }\end{array}$} \\
\hline & & M 40 & & \\
\hline & & $40 \mathrm{CTR}$ & & \\
\hline & & Age: $4-7$ & & \\
\hline \multicolumn{5}{|c|}{ * in the ASD group (it concerns all presented studies) } \\
\hline \multicolumn{5}{|c|}{ ** selected group from the study } \\
\hline \multicolumn{5}{|c|}{ *** LFA: low functioning autism, MFA: medium functioning autism, HFA: high functioning autism } \\
\hline \multicolumn{5}{|c|}{ CTR - control } \\
\hline \multicolumn{5}{|c|}{ F - females } \\
\hline \multicolumn{5}{|c|}{ M - males } \\
\hline
\end{tabular}


Table 2

Essential trace elements

\begin{tabular}{|c|c|c|c|c|c|c|c|c|c|c|c|c|c|}
\hline Ref. & $\begin{array}{l}\text { Statistical } \\
\text { value/unit }\end{array}$ & $\mathrm{Cr}$ & Co & & $\mathrm{Fe}$ & & Mn & & $\mathrm{Zn}$ & & $\mathrm{Cu}$ & & $\mathrm{Se}$ \\
\hline [26] & Median $/(\mu \mathrm{g} / \mathrm{g})$ & & & & $13.11(c$ & $81-$ & $0.224(0$ & $61-$ & 122.3( & $5.6-$ & 10.11 & $46-$ & $0.422(0.35$ \\
\hline & & $0.184)$ & (0.005-0. & & & & & & & & & & \\
\hline [27] & Median $/(\mu \mathrm{g} / \mathrm{g})$ & 1.151 & 0.025 & & - & & $0.144(0$ & $58-$ & $136(10$ & $-168)$ & 9.226 & $.939-$ & $0.511(0.46$ \\
\hline & & $1.714)$ & $(0.025-0$. & & & & & & & & & & \\
\hline [28] & Median/(mg/kg) & - & - & & 19.00 & & - & & 78.00 & & 8.30 & & - \\
\hline [29] & Median/( $\mu \mathrm{g} / \mathrm{g})$ & 0.110 & 0.008( & & $12.37(c$ & $44-$ & $0.254(0$ & 94- & $121.5 \mathrm{c}$ & 77.17- & 9.60 & $.454-$ & $0.341(0.26$ \\
\hline & & $0.150)$ & $0.006-0.0$ & & & & & & & & & & \\
\hline [30] & Median/( $\mu \mathrm{g} / \mathrm{g})$ & - & $\begin{array}{l}0.0066(0 . \\
0.0104)^{\star}\end{array}$ & 048- & $\begin{array}{l}11.7(9 . \\
18.5)^{\star}\end{array}$ & & $\begin{array}{l}0.2233( \\
0.3220)\end{array}$ & 1384- & $122(77$ & $169)^{\star}$ & $\begin{array}{l}10.9 \\
13.3)^{\star}\end{array}$ & & $\begin{array}{l}0.4061(0.3 \\
0.4598)^{\star}\end{array}$ \\
\hline [31] & Median $/(\mu \mathrm{g} / \mathrm{g})$ & - & $\begin{array}{l}0.0111 \\
(0.0086- \\
0.0157)\end{array}$ & $\begin{array}{l}0.0068 \\
(0.0048- \\
0.0104)\end{array}$ & $\begin{array}{l}16.0 \\
(11.5- \\
22.9)\end{array}$ & $\begin{array}{l}10.5 \\
(8.8- \\
15.7)\end{array}$ & $\begin{array}{l}0.326 \\
(0.195- \\
0.469)\end{array}$ & $\begin{array}{l}0.241 \\
(0.174- \\
0.340)\end{array}$ & $\begin{array}{l}77.0 \\
(63.8- \\
141.8)\end{array}$ & $\begin{array}{l}153.2 \\
(117.3- \\
202.0)\end{array}$ & $\begin{array}{l}10.6 \\
(8.8- \\
12.5)\end{array}$ & $\begin{array}{l}8.7 \\
(8.2- \\
11.1)\end{array}$ & $\begin{array}{l}0.364 \\
(0.317- \\
0.407)\end{array}$ \\
\hline [32] & Median $/(\mu \mathrm{g} / \mathrm{g})$ & 0.110 & 0.008 & & $11.7(9$. & & $0.230(0$ & 70- & - & & 10.2( & & $0.365(0.31$ \\
\hline & & * & $(0.006-0$. & & & & & & & & & & \\
\hline [33] & ** & 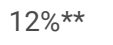 & $2.0 \%$ ** & & $17 \%$ ** & & $4 \% \star \star$ & & $29.7 \%$ * & & $4 \% \star \star$ & & - \\
\hline [34] & $\begin{array}{l}\text { Mean + } \\
\mathrm{SD} /(\mu \mathrm{g} / \mathrm{g})\end{array}$ & $\begin{array}{l}0.09 \pm \\
0.06\end{array}$ & $0.04 \pm 0.0$ & & $10.89 \pm$ & .28 & $0.38 \pm 0$ & & 101.04 & \pm 52.0 & 21.94 & 21.7 & $0.80 \pm 0.25$ \\
\hline [35] & Median $/(\mu \mathrm{g} / \mathrm{g})$ & 0.20 & 0.01 & & 7.60 & & 0.20 & & 149.00 & & 10.20 & & 0.90 \\
\hline [36] & Mean +- & LFA & - & & - & & - & & 130.46 & 15.65 & 36.62 & 4.39 & $0.57 \pm 0.06$ \\
\hline & & MFA & & & & & & & 172.81 & 20.73 & 23.16 & 2.77 & $1.98 \pm 0.23$ \\
\hline & & HFA & & & & & & & 171.92 & 20.63 & 12.35 & 1.48 & $2.55 \pm 0.30$ \\
\hline [37] & Median $/(\mu \mathrm{g} / \mathrm{g})$ & - & - & & - & & - & & - & & - & & - \\
\hline
\end{tabular}


Table 3

Concentration of metals

\begin{tabular}{|c|c|c|c|c|c|c|c|c|c|c|c|c|c|}
\hline Ref. & \multicolumn{2}{|l|}{$\mathrm{Li}$} & \multicolumn{2}{|l|}{$\mathrm{Be}$} & \multicolumn{2}{|l|}{ Al } & $\mathrm{Ni}$ & \multicolumn{2}{|l|}{ As } & Mo & \multicolumn{2}{|l|}{$\mathrm{Cd}$} & $\mathrm{Hg}$ \\
\hline [26] & \multicolumn{2}{|l|}{0.023} & \multirow{2}{*}{\multicolumn{2}{|c|}{-}} & \multirow{2}{*}{\multicolumn{2}{|c|}{-}} & - & \multirow{2}{*}{\multicolumn{2}{|c|}{-}} & - & \multirow{2}{*}{\multicolumn{2}{|c|}{ - }} & \multirow[t]{2}{*}{-} \\
\hline & \multicolumn{2}{|c|}{$(0.017-0.034)$} & & & & & & & & & & & \\
\hline [27] & \multicolumn{2}{|l|}{0.025} & \multicolumn{2}{|l|}{0.025} & \multirow{2}{*}{\multicolumn{2}{|c|}{$\begin{array}{l}7.738(5.797- \\
12.79)\end{array}$}} & 0.158 & \multirow{2}{*}{\multicolumn{2}{|c|}{$\begin{array}{l}0.082 \\
(0.030-0.165)\end{array}$}} & \multirow{2}{*}{$\begin{array}{l}0.117 \\
(0.051- \\
0.179)\end{array}$} & \multirow{2}{*}{\multicolumn{2}{|c|}{$\begin{array}{l}0.021 \\
(0.010-0.035)\end{array}$}} & \multirow{2}{*}{$\begin{array}{l}0.338 \text { (( } \\
1.255)\end{array}$} \\
\hline & \multicolumn{2}{|c|}{$(0.025-0.025)$} & \multicolumn{2}{|c|}{$(0.025-0.025)$} & & & $0.365)$ & & & & & & \\
\hline [28] & - & & - & & \multicolumn{2}{|l|}{-} & - & \multicolumn{2}{|l|}{0.21} & - & \multicolumn{2}{|l|}{0.04} & 0.41 \\
\hline [29] & \multicolumn{2}{|l|}{-} & \multicolumn{2}{|l|}{-} & \multicolumn{2}{|l|}{-} & - & \multicolumn{2}{|c|}{$0.033(0.023-0.039)$} & - & \multicolumn{2}{|c|}{$0.022(0.015-0.030)$} & $\begin{array}{l}0.229(1 \\
0.393)\end{array}$ \\
\hline [30] & \multicolumn{2}{|l|}{-} & \multicolumn{2}{|l|}{-} & \multicolumn{2}{|l|}{-} & - & \multicolumn{2}{|l|}{-} & - & - & & - \\
\hline [31] & $\begin{array}{l}0.0165 \\
(0.0119- \\
0.0470)\end{array}$ & $\begin{array}{l}0.0202 \\
(0.0115- \\
0.0290)\end{array}$ & $\begin{array}{l}0.0005 \\
(0.0003- \\
0.0007)\end{array}$ & $\begin{array}{l}0.0006 \\
(0.0003- \\
0.0008)\end{array}$ & $\begin{array}{l}8.8 \\
(7.4- \\
19.1)\end{array}$ & $\begin{array}{l}9.2 \\
(5.3- \\
11.8)\end{array}$ & - & $\begin{array}{l}0.0391 \\
(0.0284- \\
0.0591)\end{array}$ & $\begin{array}{l}0.0301 \\
(0.0250- \\
0.0408)\end{array}$ & - & $\begin{array}{l}0.0277 \\
(0.0224- \\
0.0617)\end{array}$ & $\begin{array}{l}0.0222 \\
(0.0149- \\
0.0297)\end{array}$ & $\begin{array}{l}0.116 \\
(0.066- \\
0.203)\end{array}$ \\
\hline [32] & 0.020 & & $0.0004(0$. & $001-$ & $8.0(5$. & & - & 0.034 & & - & 0.023 & & $0.127(1$ \\
\hline & $(0.012-0$ & & & & & & & $(0.021-0$ & & & $(0.014-0$. & 35) & \\
\hline [33] & - & & - & & - & & - & - & & - & - & & - \\
\hline [34] & $0.002 \pm 0$ & & $0.0001 \pm 0$ & 003 & $8.89 \pm$ & .16 & $\begin{array}{l}0.55 \pm \\
0.83\end{array}$ & $0.20 \pm 0.2$ & & $\begin{array}{l}0.08 \pm \\
0.1\end{array}$ & $0.23 \pm 0.27$ & & $0.47 \pm C$ \\
\hline [35] & 0.008 & & & & 11.65 & & 0.20 & 0.03 & & 0.04 & 0.01 & & 0.50 \\
\hline [36] & LFA & & - & & - & & - & - & & - & - & & $3.09 \pm C$ \\
\hline & MFA & & & & & & & & & & & & $1.10 \pm C$ \\
\hline & HFA & & & & & & & & & & & & $0.65 \pm C$ \\
\hline [37] & - & & $0.05(0.01$ & .10) & $\begin{array}{l}61.0(5 \\
70.0)\end{array}$ & & - & $0.13(0.12$ & $0.18)$ & - & $0.14(0.12$ & $0.16)$ & $4.50(4$. \\
\hline
\end{tabular}

\section{Discussion}

According to WHO, the fraction of autistic children in the population is increasing. Today, 1 in 160 children is diagnosed for ASD. The incidence of ASD has increased significantly in the last 10 years. This is believed to be related with environmental pollution which, is a consequence of urbanization and industrialization [38].

Research on the status of trace elements and their relationship to ASD is carried out using various exposure biomarkers: hair mineral analysis, blood, urine and teeth compartments. Autism is also considered as one of the forms of $\mathrm{Hg}$ poisoning. Some micronutrients, such as $\mathrm{Cu}$, may contribute to the development of ASD. In turn, Zn plays a protective role against neurodevelopmental problems, as it participates in detoxification and antioxidation, with the participation of e.g. metallothioneins [31].

\subsection{Toxic elements and ASD}

Due to the increasing number of autism cases, environmental factors (exposure to toxic substances) are believed to contribute to the pathogenesis of ASD (Table 4). Children are more likely to be exposed to environmental toxins as they have a higher absorption rate and a lower detoxification capacity than adults. $\mathrm{Hg}$ is believed to contribute in the highest extent to the ASD pathogenesis due to its neurotoxicity. Thiomersal (an organic compound of mercury) present in vaccines as a preservative, e.g. in Measles-Mumps-Rubella, also used as an antiseptic and antifungal agent, has long been thought to have contributed to a large fraction of autism cases. The problems with the metabolism of toxic elements in autistic children are believed to be related to oxidative stress, reduced potential for methylation and trans-sulfuration, as well as mitochondrial dysfunction. In addition, children with autism have higher levels of porphyrins in their urine, which is related to the mercury load in the body [39].

An interesting interpretation is the link between ASD and biomarkers using metallomics (biometal studies) in combination with genomics and proteomics. Meta-analysis study showed a relationship between ASD and Cu, Fe, Zn. The results of studies on patients with ASD showed higher levels of Cu that was related with oxidative damage, Fe deficiency causing anemia, behavioral and emotional problems, lower $\mathrm{Zn}$ content, which is associated with autoimmune infection, hyperactivity and mental retardation. Studies have shown that too high Cu administration causes $\mathrm{Zn}$ deficiency and is associated with synaptic dysfunction. The optimal $\mathrm{Zn} / \mathrm{Cu}$ value was suggested at the level of 0.66-0.81 [40].

Scientific literature emphasizes the important role played by glutathione in ASD pathogenesis, as it is significant in maintaining the redox balance within cells. In ASD low levels of reduced glutathione and elevated levels of oxidized glutathione are observed. This results in the malfunction of glutathione-related enzymes in the blood and brain. Exposure to toxic metals is reported to inhibit synthesis and increase glutathione excretion. Low levels of reduced glutathione 
cause oxidative stress, which is an important factor in inflammation of the nervous system. In turn, the effect of low levels of reduced glutathione causes lower capability to eliminate toxic metals from the body, the consequence of which can be ASD [18].

The etiology of pathophysiology leading to autism is usually difficult to be identified unequivocally. The genetic and environmental factors were indicated. For example, the effects of a low level of iodine and lithium in hair of mother of the child and, consequently, the child were identified. There was a correlation between the severity of autism and the content of toxic elements such as $\mathrm{Pb}$ or $\mathrm{Hg}$ in hair [41].

The toxic metals contributing to the aetiology of ASD include: mercury ( $\mathrm{Hg})$, lead (Pb), aluminum (Al) and the metalloid arsenic (As). The pathogenetic mechanism of ASD is still not fully understood. Nerve inflammation in various areas of the brain, increased cytokine inflammatory profile, abnormal expression of the kappa B factor, are indicated. Due to the increasing level of environmental pollution, the impact of exposure to toxic metals on the appearance of neurodevelopmental disorders is of particular importance [42].

Fiore et al. showed that there is a statistically significant and positive relationship between the content of Pb, Al, As, Cd in hair and the severity of ASD symptoms, including repetitive and restricted behavior, communication deficits. The content of $\mathrm{Pb}$, Mo and Mn in the hair was antagonistic with respect to the cognitive level measured as an IQ. In turn, low zinc content was associated with the severity of ASD symptoms [43].

Table 4

Toxic metals, their chemical forms and the mechanism contributing to ASD

\begin{tabular}{|c|c|c|}
\hline Metal & Chemical form & Mechanism of ASD contribution \\
\hline \multirow[t]{3}{*}{$\mathrm{Hg}$} & & $\begin{array}{l}\text { higher level of antineuronal antibodies; neurological, motor, immune and sensory dysfunctions [44]; Exposure to Hg can also be } \\
\text { caused by contamination of fish with methylmercury or a fungicide (the same compound), commonly used as a grain } \\
\text { preservative in bread [37]. Children with ASD have higher levels of Hg in the primary teeth and blood. Hg causes } \\
\text { metallothionein dysfunction. This is one of the consequences of the Zn deficit [30]. }\end{array}$ \\
\hline & $\begin{array}{l}\text { Mercury ions } \\
\left(\mathrm{Hg}^{2+}\right)\end{array}$ & are nephrotoxic and damage muscle tissue [5] \\
\hline & $\begin{array}{l}\text { Methylmercury } \\
\left(\mathrm{CH}_{3} \mathrm{Hg}^{+}\right)\end{array}$ & $\begin{array}{l}\text { is the most toxic form, capable of crossing the blood-brain barrier. Due to its lipophilic nature, it binds to neurons and is } \\
\text { therefore highly neurotoxic. The main source of methylmercury for humans are fish, bacteria and algae, which lead to the } \\
\text { biotransformation of elemental Hg to methylmercury [5]. }\end{array}$ \\
\hline As & & $\begin{array}{l}\text { alters brain morphology, depression of Mcl- } 1 \text { in the cerebral cortex; causes degeneration of gliosis, up-regulation of Bax and } \\
\text { Bak expression; contributes to impaired neurite growth through suppression of AMPK kinase activation; inhibits Wnt/ } \beta \text {-catenin } \\
\text { signalling pathway. }\end{array}$ \\
\hline $\mathrm{Pb}$ & & $\begin{array}{l}\text { causes neuroinflammation and autoimmunity. Stimulates the synthesis of the anti-ribosomal } \mathrm{P} \text { antibodies serum. Another } \\
\text { theory of the pathogenesis of autism is exposure to } \mathrm{Pb} \text { derived from leaded gasoline, which was commonly used in the past } \\
\text { [37]. }\end{array}$ \\
\hline Al & & $\begin{array}{l}\text { interacts with many glycolytic enzymes; inhibits the synthesis of cellular energy; intensifies the neurotoxic effect; } \mathrm{Al}^{3+} \text { ion by } \\
\text { oxygen-based ligands; activation of microglia that produce IL-6, TNF-a, iNOS, NOS-2, neuroinflammatory PICs and ROS. }\end{array}$ \\
\hline$u$ & & $\begin{array}{l}\text { another toxicant that may contribute to autism is uranium from coal combustion and phosphate fertilizers. There was a higher } \\
\text { level of uranium determined in the hair of autistic children (non-radioactive isotope) compared to controls [37]. }\end{array}$ \\
\hline
\end{tabular}

\section{Microelements and ASD}

Many studies show unequivocally that nutritional deficiencies may contribute to the pathogenesis of ASD (Table 5). The relationship between ASD and Fe deficiency has been pointed out. ASD and iron deficiency have been found to coexist in patients [45].

In recent years, many studies have been published comparing the content of trace elements in hair ( $\mathrm{Cu}, \mathrm{Zn}, \mathrm{Mg}$, Se). Criteria that were analyzed include age and gender, and the control group of healthy children. In the event of an increased level of toxic elements, it is possible to implement a detoxification program, e.g. with chelators (such as EDTA), to detoxify the organism from toxic metals [41].

There is a theory that excitatory and inhibitory synaptic dysfunction is the cause of ASD, and trace elements are involved [46]. 
Table 5

Microelements, their chemical forms and the ASD protectory role.

\begin{tabular}{|c|c|c|}
\hline Metal & $\begin{array}{l}\text { Chemical } \\
\text { form }\end{array}$ & Mechanism of ASD contribution \\
\hline $\mathrm{Zn}$ & & $\begin{array}{l}\text { Zinc is required for scaffolding of ProSAP/Shank proteins, which are associated with excitatory synapses. Too much zinc causes } \\
\text { epileptogenesis, and too low doses - depression and ASD. Abnormal zinc levels are indisputably associated with brain } \\
\text { malfunctions. Too high doses of copper are antagonistic to zinc and result in dysfunction of the synapses [46]. Zn is located at } \\
\text { the active site of } 300 \text { enzymes [30]. }\end{array}$ \\
\hline $\mathrm{Mg}$ & & $\begin{array}{l}\text { Important factor in ASD is also the synthesis of the key neurotransmitter gamma-aminobutyric acid (GABA). The activity of GABA } \\
\text { is regulated by magnesium ions [46]. }\end{array}$ \\
\hline $\mathrm{Fe}$ & & $\begin{array}{l}\text { Iron is a very important element involved in the proper functioning of the brain through gene expression and myelination. Iron } \\
\text { homeostasis is impaired in neurodegenerative diseases. Fe deficiency causes depression and anxiety, social and emotional } \\
\text { behavior, and thus contributes to ASD [46]. }\end{array}$ \\
\hline $\mathrm{Zn} / \mathrm{Cu}$ & & $\begin{array}{l}\text { It was shown that in children with ASD, the } \mathrm{Zn} / \mathrm{Cu} \text { ratio and } \mathrm{Zn} \text { content was significantly lower than in healthy children. The ratio } \\
\text { of } \mathrm{Zn} \text { to Cu plays a role in ASD [30]. }\end{array}$ \\
\hline $\begin{array}{l}\text { Other } \\
\text { elements }\end{array}$ & & In the case of the content of $\mathrm{Cr}$, I, Se in hair, no association with ASD was demonstrated [30]. \\
\hline
\end{tabular}

In a study on 40 autistic and healthy boys, the content of $\mathrm{Sb}, \mathrm{As}, \mathrm{U}, \mathrm{Be}, \mathrm{Hg}, \mathrm{Cd}, \mathrm{Al}, \mathrm{Be}$ and $\mathrm{Pb}$ was found. It has been proven that the hair of children with autism had significantly higher levels of $\mathrm{Pb}, \mathrm{Hg}$ and $\mathrm{U}$. The ratio between the content of nutritional and toxic elements did not differ between autistic and healthy children [37].

Studies on 52 boys in the group with ASD and 52 in the control group showed that the content of Co, Mg, Mn and V in the hair of ASD patients was significantly lower. Factor analysis showed that ASD was associated with a reduction of the levels of Co, Fe, Mg, Mn and V in the hair. The Zn content was $20 \%$ lower. The authors of the study conducted a factor analysis which showed that ASD was associated with a different level in the hair of many elements. On the other hand, regression models showed that the content of $\mathrm{Zn}$ and $\mathrm{Mg}$ in hair was negatively correlated with the intensity of neurodevelopmental disorders. Moreover, the authors observed a relationship between the content of the same elements in hair in the case of ASD and ADHD. Therefore, it has been hypothesized that supplementation with $\mathrm{Mg} \mathrm{Mn}$ and $\mathrm{Zn}$ in children with ASD and ADHD should be helpful, however it is necessary to conduct clinical trials in the future to confirm it [47].

Skalny et al. performed a study of the elemental composition of hair in 74 children with ASD in relation to 74 children from the control group. These children were divided into groups of the same sex and age (2-4 years and 5-9 years). Children diagnosed with ASD had lower Cr, I and V content in their hair. However, the Se content was higher. Children with ASD had lower levels of Be and Sn, As, B and Be. In this study, no statistically significant differences in the levels of $\mathrm{Hg}, \mathrm{Zn}$ and $\mathrm{Cu}$ in the hair were found. Overall, the authors of this study concluded that children with ASD had a lower content of all elements in their hair, both essential and toxic [32].

The content of elements in the hair of 99 children with ASD was determined. The greatest differences in the levels of elements were found in the younger group of children with ASD than in the group of older ASD patients. This study showed a reduced level of $\mathrm{Cu}, \mathrm{As}, \mathrm{Be}, \mathrm{Cd}$ and I and a higher level of Al, Fe and Se as compared with healthy children [31].

In the analysis of hair composition in 52 boys, it was found that in children with ASD, the content of the following elements was significantly lower: Co, Fe, Mg, $\mathrm{Mn}$, and $\mathrm{V}$. The regression method showed that the $\mathrm{Zn}$ and $\mathrm{Mg}$ content in the hair was negatively related with intensification of neurodevelopmental disorders [48].

Tinkov et al. investigated the relationship between the content of elements in the hair and the concentration in blood serum in boys suffering from ASD with catatonia $(\mathrm{N}=30)$ and without $(\mathrm{N}=30)$. It was found that the content of $\mathrm{Ca}$ and $\mathrm{Se}$ in hair and blood serum in patients with ASD was lower. On the other hand, the $\mathrm{Hg}$ content in the hair was 3 times higher in children with ASD and catatonia, and 2 times higher in children without catatonia. The level of I was the lowest for ASD and catatonia, and Mn was the highest in this group. In turn, the serum levels of Al and Cd were lower, and the concentrations of Cr, Cu and V - higher in patients with ASD than in the control. Multiple regression analysis showed that $\mathrm{Hg}$ content in hair and serum Al and Cd were associated with ASD [49].

Yasuda and Tsutsui [50] carried out study on the determination of 26 trace elements on the scalp hair of 1967 children. The epigenetic role of mineral disorders in children in the pathogenesis of autism was investigated. It was found that children with ASD were deficient in Zn and Mg. Increased levels of Al, $\mathrm{Cd}, \mathrm{Pb}, \mathrm{Hg}$ and As have also been demonstrated in children with ASD compared to healthy children. In another study [51], results were presented for the content of other elements. In ASD patients deficiency of $\mathrm{Zn}, \mathrm{Mg}, \mathrm{Ca}$ and increased content of $\mathrm{Al}, \mathrm{Cd}, \mathrm{Pb}, \mathrm{Hg}$, As were found. It has been shown that $\mathrm{Zn}$ and $\mathrm{Mg}$ deficiency in infants or excessive exposure to toxic elements can cause epigenetic changes in genes that are responsible for the genetic regulation of neurodevelopment in children with ASD. The same authors have shown in another study that zinc deficiency can epigenetically cause the pathogenesis of autism. The role of the nutritional approach in preventing and treating ASD was highlighted [33]. The role of the so-called "infantile window" as critical in the neurological development of ASD was underlined. It has been concluded that metallomic screening in early childhood development can be an important diagnostic and therapeutic tool in the prevention of ASD [50].

\section{Conclusions}


It is known that toxic elements, such as $\mathrm{As}, \mathrm{Pb}, \mathrm{Hg}$ influence brain development. Many studies document the association between the severity of autism symptoms and the degree of exposure to toxic elements. However, conclusive evidence is still lacking.

Research on the hair mineral level of patients with ASD is related with the fact that hair is one of the mechanisms of the excretion of toxic elements from the human organism. Most studies show that children with ASD have a problem with more profound alteration of metal handling and excretion of toxic metals.

Scientific literature has proven a positive relationship between the occurrence of ASD and the levels of toxic metals in children's hair. A relationship between lower zinc content in hair and the occurrence of ASD was found. The mechanisms that cause the imbalance in the mineral balance in the organism of patients suffering from ASD are still unknown. There is a need to continue the research in the field of clinical metallomics related to the specific symptoms of ASD. This will enable the identification of environmental risk factors, especially in the early stages of development. The important role of elements such as Mg, Mn and $\mathrm{Zn}$ as protecting against ASD was also indicated.

The variety of conclusions from the available literature may be related to interactions between genes and the environment as a complex cause of ASD. Virtually all works emphasize the change in the status of elements, both non-essential/toxic and essential, in the hair of children with neurodevelopmental disorders such as ASD. However, there are no clear, quantitative and comparable studies, because no standardized guidelines for HMA testing have been elaborated.

\section{Abbreviations}

\begin{tabular}{|ll|}
\hline ADHD & Attention Deficit Hyperactivity Disorder \\
\hline ASD & Autism Spectrum Disorder \\
\hline HMA & Hair Mineral Analysis \\
\hline
\end{tabular}

\section{Declarations}

\section{Author Contributions:}

Conceptualization, M. Mikulewicz and K. Chojnacka; methodology, M. Mikulewicz and K. Chojnacka; resources, M. Mikulewicz and K. Chojnacka; writingoriginal draft preparation, M. Mikulewicz and K. Chojnacka; writing-review and editing, M. Mikulewicz and K. Chojnacka; funding acquisition, Marcin Mikulewicz. All authors have read and agreed to the published version of the manuscript.

\section{Funding:}

This research was funded by Wroclaw Medical University.

\section{Conflicts of Interest:}

The authors declare no conflict of interest. The funders had no role in the design of the study; in the collection, analyses, or interpretation of data; in the writing of the manuscript, or in the decision to publish the results.

\section{Data availability statement:}

All data generated or analysed during this study are included in this published article (and its supplementary information files).

\section{References}

1. Virolainen S, Hussien W, Dalibalta S (2020) Autism spectrum disorder in the United Arab Emirates: potential environmental links. Rev Environ Health 0:111. https://doi.org/10.1515/reveh-2020-0025

2. ljomone OM, Olung NF, Akingbade GT, et al (2020) Environmental influence on neurodevelopmental disorders: Potential association of heavy metal exposure and autism. J Trace Elem Med Biol 62:126638. https://doi.org/10.1016/j.jtemb.2020.126638

3. Currenti SA (2010) Understanding and determining the etiology of autism. Cell Mol Neurobiol 30:161-171. https://doi.org/10.1007/s10571-009-9453-8

4. Kern JK, Geier DA, Sykes LK, et al (2016) The relationship between mercury and autism: A comprehensive review and discussion. J Trace Elem Med Biol 37:8-24. https://doi.org/10.1016/j.jtemb.2016.06.002

5. Modabbernia A, Velthorst E, Reichenberg A (2017) Environmental risk factors for autism: an evidence-based review of systematic reviews and metaanalyses. Mol Autism 8:1-16. https://doi.org/10.1186/s13229-017-0121-4

6. Adams JB, Holloway CE, George F, Quig AD (2006) Analyses of Toxic Metals and Essential Minerals in the Hair of Arizona Children with Autism and Associated Conditions, and Their Mothers

7. Semenova Y, Zhunussov Y, Pivina L, et al (2019) Trace element biomonitoring in hair and blood of occupationally unexposed population residing in polluted areas of East Kazakhstan and Pavlodar regions. J Trace Elem Med Biol 56:31-37. https://doi.org/10.1016/j.jtemb.2019.07.006

8. Savinov SS, Sharypova RM, Drobyshev Al (2020) Determination of the Trace Element Composition of Human Nails. J Anal Chem 75:409-415. https://doi.org/10.1134/S1061934820030168 
9. Esplugas R, Mari M, Marquès $M$, et al (2019) Biomonitoring of trace elements in hair of schoolchildren living near a hazardous waste incinerator-a 20 years follow-up. Toxics 7:1-11. https://doi.org/10.3390/toxics7040052

10. Cole SA (2020) Individual and collective identification in contemporary forensics. Biosocieties 15:350-375. https://doi.org/10.1057/s41292-018-0142-z

11. Alekseenko SI, Skalny A V., Karpischenko SA, Tinkov AA (2020) Serum, Whole Blood, Hair, and Mucosal Essential Trace Element and Mineral Levels in Children with Verified Chronic Rhinosinusitis Undergoing Functional Endoscopic Sinus Surgery. Biol Trace Elem Res. https://doi.org/10.1007/s12011-02002333-2

12. Çelik B, Nalçacıoğlu H, Karakükçü Ç, et al (2020) Assessment of Hair Zinc in the School Children in Kayseri, Turkey. Biol Trace Elem Res 196:343-348. https://doi.org/10.1007/s12011-020-02115-w

13. Sazakli E, Leotsinidis M (2017) Hair biomonitoring and health status of a general population exposed to Nickel. J Trace Elem Med Biol 43:161-168. https://doi.org/10.1016/j.jtemb.2017.02.001

14. Shin WJ, Jung M, Ryu JS, et al (2020) Revisited digestion methods for trace element analysis in human hair. J Anal Sci Technol 11:1-5. https://doi.org/10.1186/s40543-019-0200-6

15. Zhang S, Chu Y, Ma S, et al (2020) Highly accurate determination of Zn and Cu in human hair by ultrasound-assisted alkali dissolution combined with laser-induced breakdown spectroscopy. Microchem J 157:105018. https://doi.org/10.1016/j.microc.2020.105018

16. Bocato MZ, Bianchi Ximenez JP, Hoffmann C, Barbosa F (2019) An overview of the current progress, challenges, and prospects of human biomonitoring and exposome studies. J Toxicol Environ Heal - Part B Crit Rev 22:131-156. https://doi.org/10.1080/10937404.2019.1661588

17. Peña-Fernández A, del Carmen Lobo-Bedmar M, González-Muñoz MJ (2017) Effects of sex on the levels of metals and metalloids in the hair of a group of healthy Spanish adolescents (13 to 16 years old). Environ Sci Pollut Res 24:23666-23678. https://doi.org/10.1007/s11356-017-9984-3

18. Bjørklund G, Tinkov AA, Hosnedlová B, et al (2020) The role of glutathione redox imbalance in autism spectrum disorder: A review. Free Radic Biol Med 160:149-162. https://doi.org/10.1016/j.freeradbiomed.2020.07.017

19. Li P, Guo S, Zhao J, et al (2019) Human Biological Monitoring of Mercury Through Hair Samples in China. Bull Environ Contam Toxicol $102: 701-707$. https://doi.org/10.1007/s00128-019-02563-8

20. Protano C, Astolfi ML, Marconi E, et al (2019) Occupational Exposure Assessment of Major and Trace Elements in Human Scalp Hair Among a Group of Eritrean Workers. Biol Trace Elem Res. https://doi.org/10.1007/s12011-019-01988-w

21. Noreen F, Sajjad A, Mahmood K, et al (2019) Human Biomonitoring of Trace Elements in Scalp Hair from Healthy Population of Pakistan. Biol Trace Elem Res. https://doi.org/10.1007/s12011-019-01906-0

22. Wei B, Yu J, Wang J, et al (2018) Trace Metals in the Urine and Hair of a Population in an Endemic Arsenism Area. Biol Trace Elem Res 182:209-216. https://doi.org/10.1007/s12011-017-1108-x

23. Wongsasuluk P, Chotpantarat S, Siriwong W, Robson M (2018) Using hair and fingernails in binary logistic regression for bio-monitoring of heavy metals/metalloid in groundwater in intensively agricultural areas, Thailand. Environ Res 162:106-118. https://doi.org/10.1016/j.envres.2017.11.024

24. Vinnikov D, Semizhon S, Rybina T, et al (2018) Occupational exposure to metals and other elements in the tractor production. PLoS One 13:1-11. https://doi.org/10.1371/journal.pone.0208932

25. Mauriello MC, Sbordone C, Montuori P, et al (2017) Biomonitoring of toxic metals in incinerator workers: A systematic review. Toxicol Lett $272: 8-28$. https://doi.org/10.1016/j.toxlet.2017.02.021

26. Skalny A V., Mazaletskaya AL, Ajsuvakova OP, et al (2020) Hair trace element concentrations in autism spectrum disorder (ASD) and attention deficit/hyperactivity disorder (ADHD). J Trace Elem Med Biol 61:126539. https://doi.org/10.1016/j.jtemb.2020.126539

27. Fiore M, Barone R, Copat C, et al (2020) Metal and essential element levels in hair and association with autism severity. J Trace Elem Med Biol 57:126409. https://doi.org/10.1016/j.jtemb.2019.126409

28. Zhai Q, Cen S, Jiang J, et al (2019) Disturbance of trace element and gut microbiota profiles as indicators of autism spectrum disorder: A pilot study of Chinese children. Environ Res 171:501-509. https://doi.org/10.1016/j.envres.2019.01.060

29. Tinkov AA, Skalnaya MG, Simashkova N V., et al (2019) Association between catatonia and levels of hair and serum trace elements and minerals in autism spectrum disorder. Biomed Pharmacother 109:174-180. https://doi.org/10.1016/j.biopha.2018.10.051

30. Skalny A V., Simashkova N V., Skalnaya AA, et al (2017) Assessment of gender and age effects on serum and hair trace element levels in children with autism spectrum disorder. Metab Brain Dis 32:1675-1684. https://doi.org/10.1007/s11011-017-0056-7

31. Skalny A V., Simashkova N V., Klyushnik TP, et al (2017) Analysis of Hair Trace Elements in Children with Autism Spectrum Disorders and Communication Disorders. Biol Trace Elem Res 177:215-223. https://doi.org/10.1007/s12011-016-0878-x

32. Skalny A V., Simashkova N V., Klyushnik TP, et al (2017) Hair toxic and essential trace elements in children with autism spectrum disorder. Metab Brain Dis 32:195-202. https://doi.org/10.1007/s11011-016-9899-6

33. Yasuda H, Yoshida K, Yasuda Y, Tsutsui T (2011) Infantile zinc deficiency: Association with autism spectrum disorders. Sci Rep 1: https://doi.org/10.1038/srep00129

34. Blaurock-Busch E; Amin O R.; Rabahamin T O (2012) Heavy metals and and trace elements in hair and urine of a sample of arab children with autistic spectrum disorder. Eur Psychiatry 27:1. https://doi.org/10.1016/s0924-9338(12)74420-6

35. De Palma G, Catalani S, Franco A, et al (2012) Lack of correlation between metallic elements analyzed in hair by ICP-MS and autism. J Autism Dev Disord 42:342-353. https://doi.org/10.1007/s10803-011-1245-6

36. Lakshmi Priya MD, Geetha A (2011) Level of trace elements (copper, zinc, magnesium and selenium) and toxic elements (lead and mercury) in the hair and nail of children with autism. Biol Trace Elem Res 142:148-158. https://doi.org/10.1007/s12011-010-8766-2

Page 11/13 
37. Fido A, Al-Saad S (2005) Toxic trace elements in the hair of children with autism. Autism 9:290-298. https://doi.org/10.1177/1362361305053255

38. Nabgha-e-Amen, Eqani SAMAS, Khuram F, et al (2020) Environmental exposure pathway analysis of trace elements and autism risk in Pakistani children population. Sci Total Environ 712:. https://doi.org/10.1016/j.scitotenv.2019.136471

39. De Palma G, Catalani S, Franco A, et al (2012) Lack of correlation between metallic elements analyzed in hair by ICP-MS and autism. J Autism Dev Disord 42:342-353. https://doi.org/10.1007/s10803-011-1245-6

40. Scassellati C, Bonvicini C, Benussi L, et al (2020) Neurodevelopmental disorders: Metallomics studies for the identification of potential biomarkers associated to diagnosis and treatment. J Trace Elem Med Biol 60:. https://doi.org/10.1016/j.jtemb.2020.126499

41. Lakshmi Priya MD, Geetha A (2011) Level of trace elements (copper, zinc, magnesium and selenium) and toxic elements (lead and mercury) in the hair and nail of children with autism. Biol Trace Elem Res 142:148-158. https://doi.org/10.1007/s12011-010-8766-2

42. Bjørklund G, Skalny A V., Rahman MM, et al (2018) Toxic metal(loid)-based pollutants and their possible role in autism spectrum disorder. Environ Res 166:234-250. https://doi.org/10.1016/j.envres.2018.05.020

43. Fiore M, Barone R, Copat C, et al (2020) Metal and essential element levels in hair and association with autism severity. J Trace Elem Med Biol 57: https://doi.org/10.1016/j.jtemb.2019.126409

44. Petrova M V., Ourgaud M, Boavida JRH, et al (2020) Human mercury exposure levels and fish consumption at the French Riviera. Chemosphere 258: https://doi.org/10.1016/j.chemosphere.2020.127232

45. Tseng PT, Cheng YS, Chen YW, et al (2018) Peripheral iron levels in children with autism spectrum disorders vs controls: a systematic review and metaanalysis. Nutr Res 50:44-52. https://doi.org/10.1016/j.nutres.2017.11.004

46. Saghazadeh A, Ahangari N, Hendi K, et al (2017) Status of essential elements in autism spectrum disorder: Systematic review and meta-analysis. Rev. Neurosci. 28:783-809

47. Skalny A V., Mazaletskaya AL, Ajsuvakova OP, et al (2020) Serum zinc, copper, zinc-to-copper ratio, and other essential elements and minerals in children with attention deficit/hyperactivity disorder (ADHD). J Trace Elem Med Biol 58:126445. https://doi.org/10.1016/j.jtemb.2019.126445

48. Skalny A V., Mazaletskaya AL, Ajsuvakova OP, et al (2020) Hair trace element concentrations in autism spectrum disorder (ASD) and attention deficit/hyperactivity disorder (ADHD). J Trace Elem Med Biol 61:126539. https://doi.org/10.1016/j.jtemb.2020.126539

49. Tinkov AA, Ajsuvakova OP, Skalny A V. (2020) A Case-Control Study of Essential and Toxic Trace Elements and Minerals in Hair of 0-4-Year-Old Children with Cerebral Palsy. Biol Trace Elem Res 195:399-408. https://doi.org/10.1007/s12011-019-01876-3

50. Yasuda H, Tsutsui T (2013) Assessment of infantile mineral imbalances in autism spectrum disorders (ASDs). Int. J. Environ. Res. Public Health 10:6027-6043

51. Yasuda H, Kobayashi M, Yasuda Y, Tsutsui T (2013) Estimation of autistic children by metallomics analysis. Sci Rep 3:. https://doi.org/10.1038/srep01199

\section{Figures}




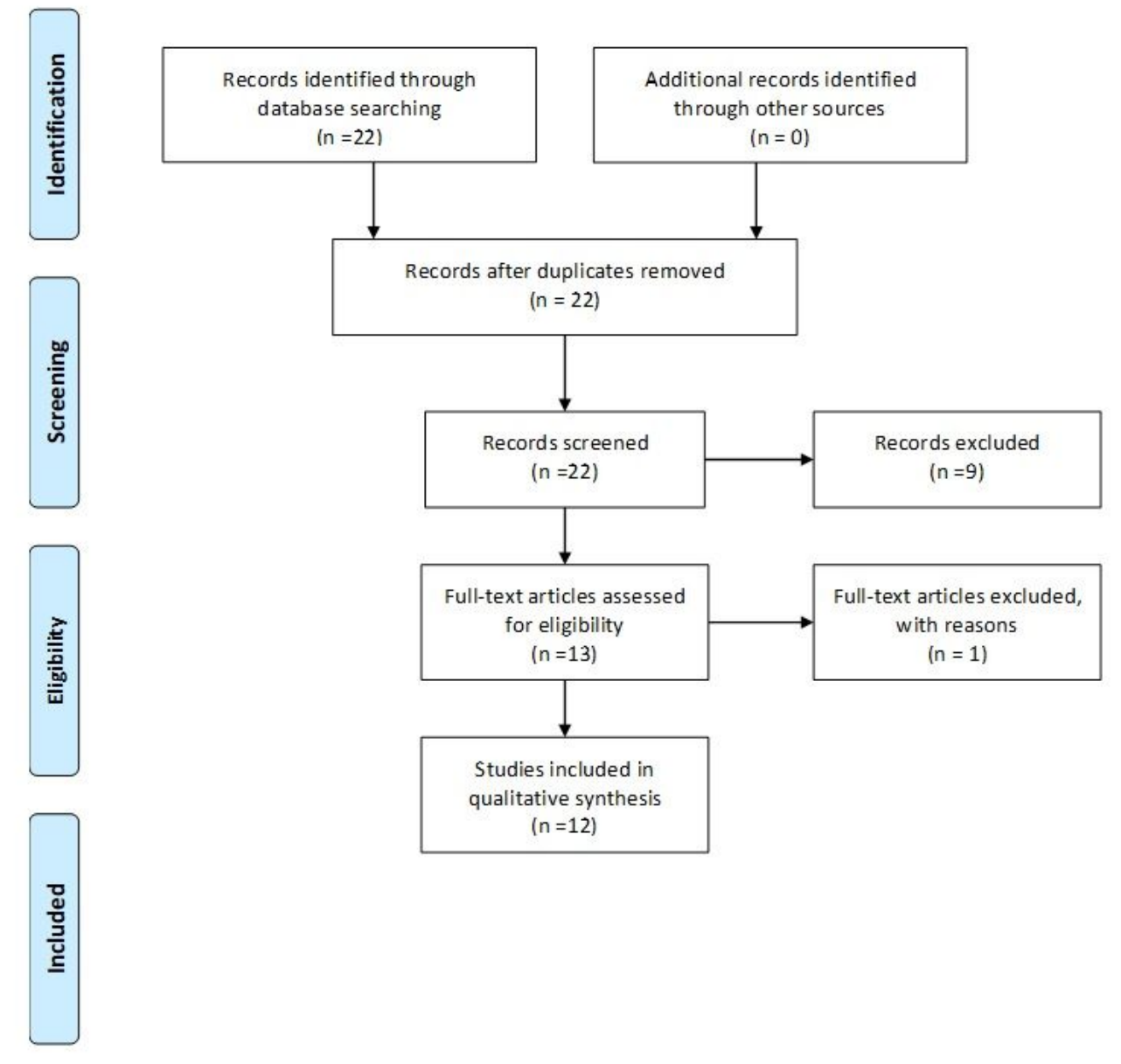

Figure 1

PRISMA flow diagram 